\title{
THE EFFECTS OF BRANDING IN THE MARKETING OF LOCALLY MANUFACTURED PRODUCTS IN GHANA- A CASE OF CHOCHO INDUSTRIRES LIMITED
}

\author{
ARMAH-BEMPONG ERIC ${ }^{1} \&$ KOFI OWIREDU GHORMAN ${ }^{2}$ \\ ${ }^{1}$ Lecturer, Perez University College, Winneba \\ PhD Candidate, Open University of Malaysia, Malaysia \\ ${ }^{2}$ Lecturer, Sunyani Technical University, Ghana
}

\begin{abstract}
Most companies and customers unfortunately, do not see the value or part, branding plays in enhancing not only the value of the product but also the image of the company. In view of this, the new competition is not between what companies produce in their factories, but between what they add to their factory output in the form of packaging, services, advertising, branding, consumer advice, final delivery arrangements, warehousing and other things that people value. It is against this background that the researcher seeks to identify the effects of branding in the marketing of locally manufactured products in Ghana, with specific reference to Chocho Industries Limited. The objectives of the study were:

- To identify the impact of branding on the corporate image of Chocho Industry Limited.

- To identify how local manufacturing firms (Chocho Industries Limited) can effectively use branding to market its products.

- To evaluate how branding influences the purchasing decision of a customer.

- To examine the benefits of branding on both manufacturer and consumers of locally manufactured products.

The researcher made use of non-probability or purposive sampling technique with specific reference to convenient sampling or accidental sampling method. Two different types of research instruments were used on a sample size of 1000 respondents, of which, 980 responded to the questionnaires as well as the interview. Thus, questionnaires and interviews were used to obtain information from the respondents. The data was analyzed using SPSS as a statistical tool. The findings of the study revealed that of Chocho Industries Limited depends much on branding, backed by advertising to create awareness of the company to the public. Branding has helped the company that yielded tremendous positive effects on the company's corporate image, sales and profit levels. It was recommended that Chocho Industries Limited improves its brand continually to motivate the customers in their choice of products.

KEYWORDS: Branding, Marketing \& Locally Manufactured Products
\end{abstract}

Received: Jul 16, 2017; Accepted: Aug 08, 2017; Published: Aug 21, 2017; Paper Id.: IJSMMRDAUG20178

\section{INTRODUCTION}

Even before 1960, when Theodore Levitt (1962) published Marketing Myopia, some businessmen realised the dangers inherent in too close an identification of the firm, with a specific product and the importance of meeting customer needs and specific products or offering. Products might have very limited lives but needs 
might persist.

Today, this issue is at the centre of marketing thought. The firm, which narrowly defines itself in terms of particular, form of product runs the risk of being overtaken by changes in the ways in which customers seek to satisfy their needs. "They have always bought it and everyone needs it" are phrases which have sounded the death-knell of or led to massive contraction in industries and companies.

Recognising the dangers inherent of this identification with specific offerings, has led to a more critical examination of how products and brands develop over time.

According to Levitt (1962), "The new competition is not between what companies produce in their factories, but between what they add to their factory output in the form of packaging, services, advertising, branding, consumer advice, final delivery arrangements, warehousing and other things that people value". Consumers view a brand as an important part of the product, and branding can add value to the product. Hence, branding decisions forms an important part of product strategy, in developing a marketing strategy for the company and its products. Branding is a major issue in product strategy. On the one hand, developing a branded product requires a deal of long term investment spending, especially, for advertising, promotion and packaging. Many brand oriented companies subcontracts manufacturing to other companies. For example, Taiwanese manufacturers a make a great amount of the world's clothing, electronic appliance and computers but not under Taiwanese brand names.

On the other hand, manufacturers eventually learn that market power lies with the brand name. Japanese and South Korean companies realized this and spent liberally to build up brand names such as Sony, Toyota, LG and Samsung. Even when these companies can no longer afford to manufacture their products in their homeland, the brand name continue to command customer loyalty.

Companies and customers today have now come to realize the significant role branding plays in the promotion of goods and services in the market. Branding generally adds some uniqueness to the product development, positioning and features to attract and articulate customers' perception. For instance, Kasapreko Company Limited, Coca-Cola Bottling Company, Toyota Ghana Limited and many others use their brand imagery to promote their products.

In some cases, certain companies and customers unfortunately do not see the value or part branding plays in enhancing not only the value of the product, but also the image of the company.

It is against this background that the researcher seeks to identify the effects of branding in the marketing of locally manufactured products in Ghana.

Chocho Industries Limited located at Suhum in the Eastern Region is among the many locally manufacturing industries in the country. Over the years, the local manufacturing sector has grown tremendously to cause the emergence of more of such industries in Ghana. This has brought about competitions among traditional or local manufacturing industries in the marketing of their products because they all produce similar products and operate in the same market.

In view of this, Chocho Industries Limited has embarked on numerous marketing mixes preferably branding to market its products as well as build preferences for their products in the Ghanaian market, and even beyond the borders of Ghana to gain competitive advantage over its competitors. The company manufactures and distributes skin care products such as chocho beauty soap and cream, chocho tea, chocho skin tonner, chocho hair food, chocho balm and many others. 


\section{OBJECTIVES}

The objectives of this study are to examine the effects of branding on manufacturing firms in Ghana. It is therefore necessary to consider the following specific objectives:

- To identify the impact of branding on the corporate image of Chocho Industry Limited.

- To identify how local manufacturing firms (Chocho Industries Limited) can effectively use branding to market its products.

- To evaluate how branding influences the purchasing decision of a customer.

- To examine the benefits of branding on both manufacturer and consumers of locally manufactured products.

\section{LITERATURE REVIEW}

Branding has emerged as a top management priority in the last decade due to the growing realization that brands are one of the most valuable intangible assets that firms have. Branding is an important part of marketing decision-making and the marketing mix because; it is one of the major ways of identifying a firm as well as its products.

The word "brand" comes from the Old Norse or Germanic root meaning "burn". This meaning is mostly used when we talk about branding an animal, or an amphora of wine, to indicate its owner; figuratively when we talk about all attributes of a product that make a lasting impression in a customer's mind.

Philip Kotler (2000) defines a brand as a name, term, sign, symbol or design or a combination of them intended to identify the goods or services of one seller or group of sellers and to differentiate them from those competitors. Hence, a brand is a product offer from a known source.

Branding according to American Marketing Association (2011) is a distinctive name and or symbol such as (logo, trademark or package design) intended to identify the goods and services of each one seller or a group of sellers and to differentiate those goods and services from those of competitors".

Helena Rubenstein (1996) highlights the intangible features of the brand in quoting a definition of a brand as: the promise of the bundle of attributes which may be tangible or invisible, rational or emotional that someone buys and that provides emotional satisfaction.

Branding involves decision that setup an identity for a product with the goal of distinguishing it from competitors' offerings

A brand is a collection of images and ideas representing an economic producer; more specifically, it refers to the concrete symbols such as a name, logo, slogan, and design scheme. Brand recognition and other reactions are created by the accumulation of experiences with the specific product or service, both directly relating to its use, and through the influence of advertising, design, and media commentary. A brand is a symbolic embodiment of all the information connected to a company, product or service. A brand serves to create associations and expectations among products made by a producer. A brand often includes an explicit logo, fonts, colour schemes, symbols, sound which may be developed to represent implicit values, ideas, and even personality. A brand is a vehicle by which marketers focus their activities. Brand also measures marketer's success. 
Branding adds value to products, apart from giving product catchy names, a brand must involve activities across the whole marketing mix, leading to brand image which conveys a set of messages to consumers such as quality, price, expected performance and status. It must however be noted that branding is not a tactical tool to differentiate product but a focus for marketing effort aimed at providing customer satisfaction.

According to Bedbury (2002) the brand, and "branding" and brand equity have become increasingly important components of culture and the economy, now being described as "cultural accessories and personal philosophies".

Some marketers distinguish the psychological aspect of a brand from the experiential aspect. The experiential aspect consists of the sum of all points of contact with the brand and is known as the brand experience. The psychological aspect, sometimes referred to as the brand image, is a symbolic construct created within the minds of people and consists of all the information and expectations associated with a product or service.

According to Kotler and Pfoertsch (2006), marketers engaged in branding seek to develop or align the expectations behind the brand experience, creating the impression that a brand associated with a product or service has certain qualities or characteristics that make it special or unique. A brand image may be developed by attributing a "personality" to or associating an "image" with a product or service, whereby the personality or image is "branded" into the consciousness of consumers. A brand is therefore one of the most valuable elements in an advertising theme, as it demonstrates what the brand owner is able to offer in the marketplace. The art of creating and maintaining a brand is called brand management. This approach works not only for consumer goods B2C (Business-to-Consumer), but also for B2B (Business-to-Business). Even in B2B marketing, branding is important. Differentiation, positioning and customer responsiveness are critical in $\mathrm{B} 2 \mathrm{~B}$ as they are in any other area.

Upon what has been reviewed on branding, the researcher thinks a brand is a name, symbol, design or combination of these which identifies the goods or services of one seller or group of sellers and differentiates them from those of other sellers. For instance, Coca-Cola has trademarked its brand name and brand mark (its special way of writing Coca-Cola) whereas Chocho Industries Limited has chocho as its brand.

Again branding is the process of continuous struggle between producers and consumers to define that promise and meaning. Simply put, branding refers to the product, its identity (how the producer identifies the product) as well as its image (how the customer views the product) and is the DNA of competitive strategy for world class business. In markets, where competition is fierce and where customers may select from among many competitive products, creating an identity through branding is essential. It is particularly vital in helping position the product in the minds of the products target market.

\section{The Reasons for Branding}

According to Matthew Healey (2008), when a brand is created and established (or get created or get established), the product is sold more and more in numbers and develops a loyalty among the consumers as the people believe in one or more of the following: best value for money, among the best or fashionable in the market, reliability over quality and safety, most ethical and environmentally friendly, and similar factors about the product.

Brand may not be merely for products but also for producing companies, colleges, schools, sports and other clubs, religious institutions, social or philanthropic organizations and even individuals celebrities. When a brand is developed, the product or entity concerned gets loyalty among consumers and commands a better price or better image or respect from 
fans, admirers or supporters.

Consumers, however, may benefit from branding. Recognizing competing products by distinct trademarks allows them to be more efficient shoppers. Consumers can recognize and avoid products with which they are dissatisfied, while becoming loyal to other, more satisfying brands. Brand loyalty often eases consumer's decision making by eliminating the need for an external search.

Furthermore, brands are also important to consumers as an information source that tells them what to expect in a product. Example, if you place an order at Kentucky Fried Chicken of the "Colonel's Original Recipe Chicken," you expect fast delivery.

A successful brand can also have a carryover effect on new products the seller introduces to the market. Branding can also benefit the seller if the brand name is used on several products. In this situation, each time the seller advertises one of its products, the others with the same brand name benefits.

To sum up, some of the reasons for branding are as follows:

- $\quad$ Build stable long-term demand.

- Add values that attract customers.

- $\quad$ Build and hold good margins

- $\quad$ Provide a platform for expansion.

- $\quad$ Protect the firm against powerful intermediaries.

- Enhance the appeal of the firm. Branding helps segment market and create a distinct image for both the company and its product.

- Increases innovation in society by giving producers an incentive to look for new features that can be protected against imitating competitors.

- With Chocho Industries Limited, the branding have assisted in the company in overcoming its competitors in the market because they are seen to be of better value and quality for money spent by customers. The name Chocho has come to be synonymous with quality herbal products, thus giving an added value to all the brands.

\section{METHODOLOGY}

This paper is based on both primary and secondary data. Primary data were collected through a structured questionnaire, which was administered personally to the customers of the various companies. Convenient sample technique has been used to interview the customers. The target population of this study was customers in Kumasi Metropolis. Among the various locally manufactured herbal cream companies in the metropolis, this study considered only Choco cream group of companies which could be considered as the most vibrant among their peers. For conducting this research, 100 customers were selected from the many customers of the company and out of this, 98 customers responded properly, the response rate is 98 percent. The questionnaire consists of different questions on what constitute branding and its effects on consumer choice on Choco products. In some instances, the questionnaire also tested how customers respond to the brand Choco. The questionnaire was developed by using the various objectives of branding and its effects on customer decision making in the locally manufactured herbal creams. 
However, some secondary data have been used in the study. The secondary data used in the study have been collected from related journals, books, newspapers and internet, etc. In this study, some statistical measures have been used to measure the benefits that both consumers and manufacturers would gain from locally manufactured products like Choco.

\section{HYPOTHESIS}

On the basis of the effects of branding in the marketing of locally manufactured products, the following hypotheses were developed for the study:

H1: Marketing of locally manufactured products depends on branding as a strategy.

H2: Marketing of locally manufactured products does not depend on branding as a strategy.

H3: There is significant relationship between Psychological branding and customer purchase in the locally manufacturing firms in Ghana. .

H4: There is no significant relationship between Psychological branding and customer purchase in the locally manufacturing firms in Ghana.

\section{ANALYSIS AND FINDINGS}

A standard self-administered questionnaire was used in this study to gather data from responding employees and customers. This instrument was used to collect data on the effects of branding in the locally manufactured products, $\mathrm{PB}=$ Psychological Branding, EP= Experiential Branding and BI= Brand Image. Tables 1 and 2 come with the reliability statistics associated with the instrument used in collecting data.

Table 1: Case Processing Summary

\begin{tabular}{|l|l|c|c|}
\hline \multicolumn{2}{|c|}{} & $\mathbf{N}$ & $\%$ \\
\hline \multirow{4}{*}{ Cases } & Valid & 378 & 100.0 \\
\cline { 2 - 4 } & Excluded $^{\mathrm{a}}$ & 0 & .0 \\
\cline { 2 - 4 } & Total & 378 & 100.0 \\
\hline
\end{tabular}

Table 1 shows the case processing summary of reliability test on the instrument used in collecting data in this study. The table shows that no item has been removed from the instrument. Thus, all items in the questionnaires were worth responding. Possibly, therefore, the instrument used in collecting data was adequately reliable.

Table 2: Reliability Statistics

\begin{tabular}{|c|c|}
\hline Cronbach's Alpha & N of Items \\
\hline 944 & 4 \\
\hline
\end{tabular}

Table 2 shows the reliability coefficient; thus the Cronbach's apha value. From the table, the reliable coefficient of .944 indicates that the instrument used in data collection was highly reliable. It must however be noted that items in the instrument were consolidated into four major items that represent PB, EP, BI and Effects of Branding.

The Statistical Package for Social Sciences (SPSS) was used for data analysis. Data analysis was backed with the normality assumption. As a result, the Shapiro-Wilk test was used to verify the normality of data. Cronbach's alpha was used to identify reliability of the instruments used in data collection. All hypotheses were tested using parametric statistical 
tools owing to the fact that data used were continuous. Moreover, their distributions were assumed to take the characteristic nature of a normal distribution. The first, second and third research hypotheses were tested using Pearson's product moment correlation test. The fourth research hypothesis was tested using stepwise multiple linear regression.

\section{RESULTS}

This part of the paper focuses on the disclosure of findings on each research hypothesis. Results are presented in view of the assumption that data employed in this study are normally or approximately normally distributed. Before findings, research hypothesis are presented, therefore, the normality of data used was verified. Table 3 comes with the Shapiro-Wilk test of normality. It is worth mentioning that $98 \%$ response rate was achieved in data collection.

Table 3: Tests of Normality

\begin{tabular}{|l|c|c|c|}
\hline \multirow{2}{*}{} & \multicolumn{3}{|c|}{ Shapiro-Wilk } \\
\cline { 2 - 4 } & Statistic & df & Sig. \\
\hline Customer retention & .867 & 378 & .402 \\
\hline PB & .864 & 378 & .321 \\
\hline EB & .889 & 378 & .122 \\
\hline BI & .894 & 378 & .542 \\
\hline
\end{tabular}

Table 3 shows statistics associated with the Shapiro-Wilk test of normality. The null hypothesis states that data on each of the variables in the table are normally or approximately normally distributed. At 5\% significance level, data on brand effects $(\mathrm{p}=.402), \mathrm{PB}(\mathrm{p}=.321), \mathrm{EB}(\mathrm{p}=.122)$ and $\mathrm{BI}(\mathrm{p}=.542)$ are normally distributed $(\mathrm{p}>.05)$. The normality assumption made is therefore satisfied. As a result, a basis for valid conclusions is established.

Table 4: Correlation between Customer purchase and BI

\begin{tabular}{|l|l|c|c|}
\hline \multicolumn{2}{|c|}{} & Customer Purchase & BI \\
\hline \multirow{4}{*}{ Customer Purchase } & Pearson Correlation & 1 & $.845^{* *}$ \\
\cline { 2 - 4 } & Sig. (2-tailed) & & .000 \\
\cline { 2 - 4 } & $\mathrm{N}$ & 378 & 378 \\
\hline \multirow{3}{*}{ BI } & Pearson Correlation & $.845^{* *}$ & 1 \\
\cline { 2 - 4 } & Sig. (2-tailed) & .000 & 378 \\
\cline { 2 - 4 } & $\mathrm{N}$ & 378 & \\
\hline \multirow{2}{*}{$* *$. Correlation is significant at the 0.05 level (2-tailed). } & \\
\hline
\end{tabular}

Table 4 shows Pearson's correlation test between customer purchase and BI. It comes with findings on the first null hypothesis, which states that marketing of locally manufactured products depends on branding as a strategy.

This hypothesis is tested at $5 \%$ significance level. From the table, this test is significant, $r(378)=.845, p=.000$. Thus, the relationship between BI and customer purchase is positively high. This implies that as brand image is enhanced, customer purchase is also enhanced in terms of locally manufactured products. There is, therefore, a higher tendency for the first null hypothesis to be accepted.

Table 5: Correlation between Customer Purchase and EB

\begin{tabular}{|l|l|c|c|}
\hline \multicolumn{2}{|c|}{} & Customer Retention & EB \\
\hline \multirow{2}{*}{ Customer Purchase } & Pearson Correlation & 1 & $.857^{* *}$ \\
\cline { 2 - 4 } & Sig. (2-tailed) & & .000 \\
\hline
\end{tabular}




\begin{tabular}{|l|l|c|c|}
\hline & $\mathrm{N}$ & 378 & 378 \\
\hline \multirow{3}{*}{ EB } & Pearson Correlation & $.857^{* *}$ & 1 \\
\cline { 2 - 4 } & Sig. (2-tailed) & .000 & \\
\cline { 2 - 4 } & $\mathrm{N}$ & 378 & 378 \\
\hline \multirow{2}{*}{$* *$. Correlation is significant at the 0.05 level (2-tailed). } & \\
\hline
\end{tabular}

Table 5 contains results of testing the second null hypothesis. This hypothesis states that marketing of locally manufactured products does not depend on branding as a strategy. This test was done at 5\% significance level. From the table, there is a higher likelihood that this hypothesis is not true, $\mathrm{r}(378)=.875, \mathrm{p}=.000$. In other words, EB and customer purchase are highly positively correlated. Thus, as experiential branding is enhanced, customer purchase improves. There is, therefore, ample evidence that the null hypothesis is not true. It is therefore rejected.

Table 6: Correlation between Customer purchase and PB

\begin{tabular}{|l|l|c|c|}
\hline \multicolumn{2}{|c|}{} & Customer Purchase & PB \\
\hline \multirow{4}{*}{ Customer Purchase } & Pearson Correlation & 1 & $.843^{* *}$ \\
\cline { 2 - 4 } & Sig. (2-tailed) & & .000 \\
\cline { 2 - 4 } & $\mathrm{N}$ & 378 & 378 \\
\hline \multirow{4}{*}{ PB } & Pearson Correlation & $.843^{* *}$ & 1 \\
\cline { 2 - 4 } & Sig. (2-tailed) & .000 & 378 \\
\cline { 2 - 4 } & $\mathrm{N}$ & 378 & \\
\hline \multirow{2}{*}{$* *$. Correlation is significant at the 0.05 level (2-tailed). } & \\
\hline
\end{tabular}

Table 6 comes with results of testing the third research hypothesis, which states that there is significant relationship between Psychological branding and customer purchase in the locally manufacturing firms in Ghana. This hypothesis was also tested at $5 \%$ significance level. From the table, this test is significant, $\mathrm{r}(378)=.843, \mathrm{p}=.000$. Evidently, PB has a high positive relationship to customer purchase. Invariably, as psychological branding is enhanced among the locally manufactured products, customer purchase is improved. There is much evidence that the third null hypothesis is not true; therefore it is considered for rejection.

The fourth null hypothesis states that there is significant no relationship between Psychological branding and customer purchase in the locally manufacturing firms in Ghana. This test is done using stepwise multiple regression analysis. Tables 7 to 9 come with its results.

Table 7: Model Summary

\begin{tabular}{|c|c|c|c|c|}
\hline Model & $\mathbf{R}$ & R Square & Adjusted R Square & Std. Error of the Estimate \\
\hline 1 & $.857^{\mathrm{a}}$ & .734 & .734 & 1.73176 \\
\hline 2 & $.934^{\mathrm{b}}$ & .872 & .871 & 1.20375 \\
\hline 3 & $.951^{\mathrm{c}}$ & .904 & .904 & 1.04205 \\
\hline a. Predictors: (Constant), PB & \\
\hline
\end{tabular}

Table 7 is the model summary of the prediction of customer purchase by PB, EB and BI. In the first model, PB accounts for about $73.4 \%$ of variance on customer purchase. In the second model, PB and EB account for about $87.1 \%$ of 
variance on customer purchase. PB, EB and BI account for about $90.4 \%$ of variance on customer retention. Each of the models in the table is strong. Yet, PB appears to account for a higher level of variance on customer purchase relative to BI and EB.

Table 8: ANOVA $^{d}$

\begin{tabular}{|c|c|c|c|c|c|c|}
\hline & Model & Sum of Squares & df & Mean Square & $\mathbf{F}$ & Sig. \\
\hline \multirow{3}{*}{1} & Regression & 3117.355 & 1 & 3117.355 & $1.039 \mathrm{E} 3$ & $.000^{\mathrm{a}}$ \\
\hline & Residual & 1127.621 & 376 & 2.999 & & \\
\hline & Total & 4244.976 & 377 & & & \\
\hline \multirow{3}{*}{2} & Regression & 3701.593 & 2 & 1850.796 & $1.277 \mathrm{E} 3$ & $.000^{\mathrm{b}}$ \\
\hline & Residual & 543.383 & 375 & 1.449 & & \\
\hline & Total & 4244.976 & 377 & & & \\
\hline \multirow{3}{*}{3} & Regression & 3838.862 & 3 & 1279.621 & $1.178 \mathrm{E} 3$ & $.000^{\mathrm{c}}$ \\
\hline & Residual & 406.114 & 374 & 1.086 & & \\
\hline & Total & 4244.976 & 377 & & & \\
\hline \multicolumn{7}{|c|}{ a. Predictors: (Constant), PB } \\
\hline \multicolumn{7}{|c|}{ b. Predictors: (Constant), PB, EB } \\
\hline \multicolumn{7}{|c|}{ c. Predictors: (Constant), PB, EB, BI } \\
\hline \multicolumn{4}{|c|}{ d. Dependent Variable: Customer purchase } & & & \\
\hline
\end{tabular}

Table 8 shows the F tests associated with models in Table 7. For each model in the table, the linear prediction of customer purchase is significant at $5 \%$ significance level $(\mathrm{p}=.000)$. Thus, the test is significant when PB serves as the sole predictor, $\mathrm{F}(1,376)=103.9, \mathrm{p}=.000$; when $\mathrm{PB}$ and EB collectively serve as predictors, $\mathrm{F}(2,375)=127.7, \mathrm{p}=.000$; and when PB, EB and BI collectively serve as predictors, $\mathrm{F}(3,74)=117.8, \mathrm{p}=.000$.

Table 9: Coefficients ${ }^{\mathrm{a}}$

\begin{tabular}{|c|c|c|c|c|c|c|c|c|}
\hline \multirow[t]{2}{*}{ Model } & & \multicolumn{2}{|c|}{$\begin{array}{c}\text { Unstandardized } \\
\text { Coefficients }\end{array}$} & \multirow{2}{*}{$\begin{array}{c}\begin{array}{c}\text { Standardized } \\
\text { Coefficients }\end{array} \\
\text { Beta }\end{array}$} & \multirow[t]{2}{*}{$\mathbf{t}$} & \multirow[t]{2}{*}{ Sig. } & \multicolumn{2}{|c|}{$\begin{array}{c}\text { Collinearity } \\
\text { Statistics } \\
\end{array}$} \\
\hline & & B & Std. Error & & & & Tolerance & VIF \\
\hline \multirow{2}{*}{1} & (Constant) & .318 & .197 & & 1.612 & .108 & & \\
\hline & $\mathrm{PB}$ & .939 & .029 & .857 & 32.241 & .000 & 1.000 & 1.000 \\
\hline \multirow{3}{*}{2} & (Constant) & -.537 & .144 & & -3.743 & .000 & & \\
\hline & PB & .580 & .027 & .529 & 21.458 & .000 & .561 & 1.781 \\
\hline & EB & .523 & .026 & .495 & 20.080 & .000 & .561 & 1.781 \\
\hline \multirow{4}{*}{3} & (Constant) & -.719 & .125 & & -5.736 & .000 & & \\
\hline & $\mathrm{PB}$ & .423 & .027 & .386 & 15.527 & .000 & .414 & 2.415 \\
\hline & EB & .412 & .025 & .390 & 16.733 & .000 & .471 & 2.123 \\
\hline & BI & .301 & .027 & .290 & 11.243 & .000 & .386 & 2.593 \\
\hline \multicolumn{4}{|c|}{$\begin{array}{l}\text { a. Dependent Variable: Customer } \\
\text { purchase }\end{array}$} & & & & & \\
\hline
\end{tabular}

Table 9 shows the coefficients associated with Tables 7 and 8. The t-tests are significant for each model at 5\% significance level. Invariably, PB significantly predicts customer purchase as a sole predictor $(p=.000)$. When PB and EB serve as co-predictors, each significantly predict customer purchase at 5\% significance level (p <.05). Also, when PB, EB and BI collectively serve as predictors, each significantly predicts customer purchase at $5 \%$ significance level (p <.05). 
Evidently, customer purchase is significantly predicted by psychological branding, experiential branding and brand image practices.

Table 10: Partial Correlations

\begin{tabular}{|l|c|c|c|c|}
\hline \multicolumn{1}{|c|}{ Variable pair } & $\begin{array}{c}\text { Control } \\
\text { variable }\end{array}$ & Original $\mathbf{r}$ & Controlled $\mathbf{r}$ & $\begin{array}{c}\text { Change } \\
\text { in } \mathbf{~}\end{array}$ \\
\hline Customer purchase*PB & PB, EB & .843 & .503 & .340 \\
\hline Customer purchase*PB & PB, EB & .857 & .626 & .231 \\
\hline Customer purchase*EB & PB,BI & .845 & .654 & .191 \\
\hline
\end{tabular}

Table 10 shows the partial correlations of customer purchase and BI; customer purchase and PB; and customer purchase and EB. The correlation between customer purchase and BI is positively strong $(r=.843)$. However, when PB and EB are controlled for, this relationship is reduced substantially $(\mathrm{r}=.503)$. Also, the strong relationship between customer purchase and $\mathrm{PB}$ is reduced $(\mathrm{r}=.626)$ when $\mathrm{BI}$ and $\mathrm{EB}$ are controlled for. Moreover, the high positive relationship between customer purchase and EB is reduced, when PB and BI are controlled for. In essence, PB, EB and BI influence and empower each other in their high positive relationship to customer purchase.

\section{CONCLUSIONS AND RECOMMENDATIONS}

The study attempted to examine the effects of branding in the marketing of locally manufactured products. Since branding has become the core of every business, as means of gaining competitive advantage, it is therefore expedient for local manufacturing companies to pay more attention to branding due to the stiff competition, duplication, adoption, counterfeiting and imitation that exist in the industry as well as in the market.

Based on the response from the respondents, the researcher saw that branding serves as a marketing tool and at the same time make a company to gain competitive advantage over its competitors, if used effectively. Again, it positively affects the maximization of a company's profit as well as state the unique features of a product that differentiate it from that of its competitors

Since majority of consumers are affected positively by the brands of Chocho Industries Limited, by way of motivating them in their choice of products, the researcher recommend that the brands of chocho industry limited should be improved periodically.

Since customers are of the opinion that Chocho brands suggest quality and performance, the researcher recommend that more emphasis should be placed on these, when developing either new or brands.

The researcher recommend that Chocho Industries Limited should use the superiority of their products in the industry as an underlying theme in their promotional campaigns, since that would help them gain more competitive advantage over their competitors.

\section{REFERENCES}

1. Armstrong, G. and Kotler. P. (2008), Principles of Marketing. 12th Edition. New York: Prentice Hall.

2. Chartered Institute of Marketing (December, 2010), Quarterly Marketing Review Report.

3. Hamish Pringle (November, 2008), Brand Immortality: How Brands Can Live Long and Prosper.

4. Jain C. Subhash, International Marketing, ( $6^{\text {th }}$ Edition), pg 449. 
5. Kevin Lane Keller (2008) Strategic Brand Management: Building, Measuring and Managing Brand Equity ( $3^{\text {rd }}$ Edition).

6. Kotler, P. (2003). Marketing Management. 11th Edition, New Jersey: Prentice Hall.

7. Kothari, C. R., (2004), Research Methodology: Methods and Techniques, 2e, New Age International Publishers, New Delhi India.

8. Matthew Healey (2008), What is Branding-Essential Design Handbook Hardcover

9. Ramesh S. Kumar (2007), Marketing and Branding: The Indian Scenario, Pearson Education India pg 65.

10. Rubenstein, H. (1996), Brand First Management, Journal of Marketing Management, Vol.12, pg12.

11. Somya Agrawal (January, 2013), Brand Strategies and Brand Myopia.

12. Saunders M., Lewis P., and Thornhill, A. (2009), Research Methods for Business Students, 4e, Pearson Education, Financial Times Press, Prentice Hall, London, UK.

13. Theodore Levitt (1962), The Marketing Mode New York: McGraw Hill pg.2

14. Tony Yeshin (2000), Integrated Marketing Communications the Holistic Approach pg 36-37 
